\title{
THE ADJECTIVE IN ENGLISH: THE "FRENCH TYPE" AND ITS PLACE IN THE HISTORY OF THE LANGUAGE
}

\author{
ISABEL MOSKOWICH
}

\section{Introduction}

Before proceeding to the analysis of the situation of attributive adjectives in earlier stages of the language I will be concerned with the characteristics of the category "adjective" in present day English and the status of participles so as to know what to include or not for my analysis. Such a goal can be only achieved by taking into consideration different criteria: morphological, semantic, syntactic and word-order (Bhat, 1994).

Up to 1800 both adjectives and substantives were considered to belong to the category of nouns though their status within it were certainly different. When dealing with adjective-nouns such criteria were basically of a semantic character since "Quality is all times by far the commonest name for what the adjective expresses" (Michael 1970: 293). The same grammars that expressed this type of ideas defended that from a syntactic point of view adjectives were not to be found alone but depending on a substantive-noun. In what follows I will try to deal with each of these factors in turn.

\section{Formal criterion}

Among the formal characteristics of English adjectives the morphological expression of number deserves mentioning. It seems to be generally accepted that adjectives lack it in the sense that they do not have a special suffix to express the plural. However, almost all grammars mention the existence of pairs of the type little/few, less/fewer, much/many where there seems to be certain constraints for selection. To such an extent is the lack of a suffix to express the plural typical of adjectives that whenever they show one they are said to be substantivised. Together with the $-s$ plural, the formation of a genitive in 's is regarded as a sign that a former adjective has become a substantive (Jespersen 1949: 215).

If lack of a formal expression of number is seen as a feature typical of adjectives in present day English we could say that some participles are, in that sense, adjectival. Participles have been traditionally dealt with as having a dual status. From the point of view of inflectional morphology they are verbs. However, from the point of view of their syntactic function, they are adjectives mainly when found in attributive position as in the sleeping baby (Lyons 1981: 110). One of the things that may make us include participles into the class of adjectives (at least for the purpose here) is that "on the whole, adjectives can only be co-ordinated if they belong to the same semantic class" (Aarts - Aarts 1982: 109) and some can as illustrated in (1). 
(1) A clever but ugly girl

*a clever but Spanish ${ }^{1}$ girl

a difficult but well-built story

From the last example in (1) we could infer that the participle is an adjective belonging to the same semantic class as difficult. In fact, -ing and -ed participles are said to be found as premodifiers in the Noun Phrase "apart from 'pure' adjectives" (Aarts - Aarts 1982: 109).

Gradability, though it may be considered primarily as a semantic characteristic, has evident effects on the morphological structure (form) of adjectives, namely, the addition of suffixes such as -er and -est. Of course, this is not a feature exclusive of adjectives in English (adverbs may be gradable too). In general, though both the forms of suffixes and their side effects on roots ${ }^{2}$ have changed, and though English seems to prefer non-synthetic comparatives and superlatives even with mono- and disyllables, they are still important in PE.

\section{Syntactic and semantic criteria}

The relation established between adjectives and other elements in the Noun Phrase is one of dependence since adjectives are regarded as elements used to define other words. In this respect, forms that externally conform to the features of adjectives dealt with before (i.e. not having a plural number suffix $-s$, not having a genitive form ' $s$ and being gradable) may not be adjectives from a syntactic point of view if they stand alone with the article as in my example (2)

(2) the dead

On the contrary, words that look like adjectives from a formal point of view and that appear modifying other elements as in (3) and (4) should then be considered adjectives.

(3) the blue book

(4) the green one

The use of pro-forms as in (4) seems to have originated precisely due to this need for adjectives to occur close to the head of a Noun Phrase from the early Modern English period onwards. However, though the use of the pro-forms one/ones is very common in present day English we can still find some instances in which adjectives may appear without it, as heads, and still be somehow different from nouns. For instance, they can be modified by an adverb whereas nouns cannot. Notwithstanding this, some type of semantic restriction in the use of adverbs modifying adjectives without an accompanying noun or pro-form seems to exist since examples such as (1a) are not to be found.

1 The nationality of the girl in the example (originally Swiss) has been changed, following Prof. Dieter Kastovsky's suggestion, so that no xenophobic intention can be inferred.

2 Such as $i$-mutation in pre-Old English times. 
Since this seems irrelevant for my present purpose here, suffice it to say that adjectives like the ones in (1a) or in (5), that is to say, adjectives obtained from verbs seem to behave in a slightly different way.

(5) the sleeping baby

Though further research is needed in this point, I will consider -ed forms similar to -ing ones as far as their adjectival character is concerned even though the "very-test"3 does not apply as in (1a). This implies, then, their inclusion among my data.

But it is precisely the question of word order within the Noun Phrase the one deserving my attention in this article. Unfortunately, there seems to be no agreement as to what a Noun Phrase is. Some authors (Jespersen 1949: 25) would consider the examples in (6) below as compound nouns rather than as Noun Phrases. In fact, in Jespersen's terminology, these "chiefly French" constructions are "compounds with post-adjunct adjectives". To my purpose here I will disregard Jespersen's opinion in considering such examples as compounds and will rather take them as Noun Phrases where the head is either pre- or post-modified by an adjective. Example (6) illustrates the very different behaviour in taking suffixes of apparently equivalent phrases.

$$
\begin{aligned}
& \text { attorney general } \\
& \text { attorneys general } \\
& \text { letter patent } \\
& \text { letter patents }
\end{aligned}
$$

This made clear, it may be useful to outline a couple of basic ideas about word order. There seem to exist certain semantic constraints upon the ordering of adjectives and nouns within the Noun Phrase. Both Greenberg (1963) and Markus (1997) mention such constraints. In Greenberg's opinion (1963: 79) it is a question of harmony with the major-constituents order in the sense that Adjective + Noun order is ambivalent. He recognises that the fact that Noun + Adjective is the predominant order in the languages examined by him, is a consequence of the general tendency for comment to follow topic.

From this same sentence-perspective, Markus (1997: 493) has very recently claimed that post-nominal adjectives tend to have a "distinctly rhematic weight" bigger than that of the head of the Noun Phrase. This is what can be observed in example (7) below.

I would like to try on something green

I would like to try on a green hat

This same principle of rhematic weight would account for the post-position of adjectives with complement as in (8). 
(8) They have a car older than mine

As for post-positioned -ing and -ed forms, I will not be concerned here with what Lass (1987: 144) calls participial phrases of the type shown in (9) below because they could be interpreted as reduced relative clauses rather than as simple Noun Phrases and I have consequently excluded them from my analysis.

(9) the man sitting there (as equivalent to "the man who is sitting there")

Regarding the semantic criterion there is a twofold observation to be made. On the one hand, and generally speaking, adjectives are said to be able to function either attributively or predicatively (Quirk et al. 1972: 231). However, some semantic restriction seems to be at work when some of them are only seen to function in one of these two ways as is the case with glad (predicative only) or former, mere (attributive only). On the other hand, the majority of attributive-only adjectives are non-gradable (Rusiecki 1985: 3) so, gradability 4 should not be considered as a characteristic typical of adjectives. It is, rather, a semantic feature that is syntactically constrained.

\section{Further remarks}

I could sum up my consideration of present day English adjectives by saying that they have been characterised by a mixture of criteria. According to Huddleston (1984: 298), most central members of the word-class adjective have four potentials and the four at the same time. The three first ones (functional potentials I, II, and III) imply that adjectives can be found functioning as predicative complements as in example (10) $)^{5}$, as pre-modifiers in an Noun Phrase (see (11)) or as post-head modifiers as in (12).

(10) they found the movie very boring they found her very excited

(11) a very active woman

(12) someone really active ever so slight a foreign accent

too hot a day

no worse a plan

far cheaper a method

The fourth characteristic traditionally considered to pertain to adjectives is gradability with its double implication of modification and inflection as in (13). Huddleston's proposal is that not all these four properties are to be found in all adjectives. In fact, what

4 Certain authors, however, insist on the fact that most adjectives are gradable when preceded by words such as very, extremely, less (Aarts 1997: 30) except those denoting material (wooden) or nationality (Spanish).

5 In this sense, not only adjectives, but also participles can be included. 
he considers non-central members of the class adjective may lack one or more of them (1984: 303) and this is also true of some participles (1984: 319).

(13)

rather intelligent

better

\section{Adjectives and the history of English}

Once adjectives in present day English have been characterised, it may be useful to ascertain to what an extent are all those criteria applicable to earlier stages of the language. At first sight, the main differences between the members of the class "adjective" nowadays and in earlier periods of the history of English seem to be of a morphological character. Such differences may be probably favoured by the change from a "highly synthetic inflecting language" in Old English to "a more analytic structure" in Middle English (Lass 1992: 94). It is a fact that the ancestors of present day English adjectives were inflected, that is to say, form was subject to function. Adjectives could be found to have a plural form and also a genitive ending. In this respect some of the formal criteria considered valid for present day English members of the class seem to be irrelevant when trying to identify them in the Old and Middle English periods.

Adjectives underwent more radical changes in Middle English than nouns. At the beginning of the Middle English period adjectives ending in a consonant had different forms for singular and plural and also for strong and weak declensions as a relic of their past. This way, final $-e$ could be found both in strong and weak declensions, except for the strong singular. It is the dropping of final $-e$ that marks the complete loss of adjectival inflection before 1400 (Fisiak 1968: 83). Besides, there are instances in Middle English of adjectives taking an $-s$ for the plural when the adjective follows the noun. Some authors refer to it as the French plural (Jespersen 1949: 43).

In accordance with what we saw in section 3, what has been said so far of adjectives could be also said of past participles. As a matter of fact, authors tend to mention the same formal characteristics for both. For instance, Mustanoja (1960: 276) mentions the inflectional ending $-e$ in monosyllabic adjectives with final consonant together with past participles and monosyllabic loanwords from French. Among the formal characteristics of adjectives the fact that sometimes we may find an $-s$ plural suffix apparently due to French influence is most outstanding. In the majority of these cases the adjective is used attributively and placed after the noun (Mustanoja 1960: 277 ) as in (14). We occasionally find adjectives with an $-s$ ending before the noun and only very rarely are they in a predicative function. Such "French Type" seems to be common in scientific, ecclesiastical and legal phrases and its use is said to last until the 16th century (Mustanoja 1960: 277).

(14) In othere places delitables (Ch. CT Fkl. 899)

It is true that they are distinguished as two different categories in present day English - participles on the one hand and derivative adjectives on the other - and this 
is so because from a syntactic point of view participles cannot take intensifiers or premodifiers whereas adjectives can as illustrated in (15).

*Joan is very amusing Peter Joan is very amusing to Peter

Both in Old and Middle English there are instances of words in constructions using beon/wesan that can be considered either as adjectives or as participles since, though it is true that they are used together with a verb to form some type of periphrasis, they can be co-ordinated with adjectives, they can take intensifiers of the swiðe type, etc. The existence of a past deverbal adjective in Old English displaying almost all relevant adjectival morphology when in attributive and nominal function is clear in (16).

(16) se foresprecena here "the aforementioned army" (weak masc. nom sg).

But it is often unclear in constructions governed by beon/wesan how to establish a participle/adjective distinction, presumably parallel to that between the present day English sentences in (17).

(17) His face is swollen

His face has swollen

Though some authors (Mustanoja 1960) tried to draw a line between these two forms based upon the distinction state/effect of an action, such a semantic criterion does not seem to be valid since both refer to an action in the past that is somehow relevant in the present. Others have resorted to concord. The probable origin of past participles accompanying $\mathrm{OE}$ beon (wesan, weorðan) is a predicate adjective as in present day English "I am pleased". In the course of time the combination comes to be regarded as an integral verbal unit, and the participle loses its adjectival character. We cannot associate, as Mitchell (1985: 727) does, the difference between adjective and participle to agreement or lack of agreement. This is not a valid rule in the sense that it does not apply under all circumstances since the singular, having no formal mark, has no possibility to show agreement.

Kisbye (1971) is to be mentioned among the group of authors defending the equality of status between adjectives and past participles in earlier stages of the language. He refers not only to formal characteristics, such as the use of similar suffixes (-lic in cublic) but also to some syntactic capacities. In examples (18) and (19) below past participles are shown to function attributively and predicatively respectively. Like adjectives, past participles may also function as nouns when preceded by the corresponding determiner (20), and they may have a pure adjectival function after copulas both in Old (21) and in Middle English (22). Finally, they can also show gradability and are, in that sense, similar to some adjectives (23).

(18) Se ofslagena cyning

(19) He wæs gelæred 
(20) Se geslagena

(21) Ic wæs nacod...ic wæs geuntrumod (Wulfstan's Homilies, in Kisbye 1971: 69)

(22) Hwere lippes schrunken ben for age (Gower CA, in Kisbye 1971: 74)

(23) Pa gelæredesatan menn

The solution to the problem is proposed by Anderson (1993). He claims the existence of one originally single category. Such category seems to have split in the course of time, probably before the end of the OE period encouraging the extension of the habban perfect to intransitives. According to this it seems that my inclusion of the participles in the corpus among adjectives is not inappropriate.

\section{Other factors}

Some other factors to be considered for the study of adjectives in attributive function include the following. When dealing with the syntactic characteristics of present day English adjectives I mentioned their need to be accompanied by pro-forms such as one/ones. This was not the case in earlier periods of the language as illustrated in the example from the Bible in (24). The lack of pro-forms in earlier periods may suppose an increment of apparently non pre-posed attributive adjectives. That is to say, the fact that no pro-form of the one-type is required makes us include such unaccompanied adjectives in the corpus inside the above-mentioned group (non preponed ones). However, they will be dealt with separately to avoid any distortions in the final results (see section 7 below).

OE: se dumba spræc

Authorised Version 1611: the dumb spake

Revised Version 1881: the dumb man spoke

Some authors affirm that Indo-European languages shifted from left to right branching, including the movement or change from the order Adjective + Noun to Noun + Adjective (Bichakian 1987: 98) to be observed as the non-marked one in languages such as Spanish. Be it as it may, it is true that the order of elements in the clause or inside the Noun Phrase changed in English and that "external linguistic factors often allow structural borrowing to reduce or increase the time span of word-order changes" (Canale 1976: 46).

In this sense, Markus's claim that there are "marginal" rules in English grammar in which the word order is controlled not only by semantics and syntax but by factors such as sentence perspective or pragmatic factors seems to come true. Following Jespersen when mentioning the French influence on adjectives, he affirms that "even the etymological background of an adjective occasionally turns out to be important for its word-order behaviour" (Markus 1997: 487). In fact, specifying adjectival attributes have always followed their heads in French. 


\section{My data}

The working of all these factors just mentioned was tested for earlier periods of the English language in order to see to what an extent the criteria we apply to PE adjectives are valid for those periods and thus, how ME adjectives are different in many aspects from PE ones. All the fragments of texts used for the present study belong to the Helsinki Corpus of English Texts (1991). Samples of all types of texts have been taken into consideration so as to provide an overview of the behaviour of qualifying adjectives in attributive position/function. ME IV is the period selected for this survey, that is to say, the period stretching from 1420 to 1500 , a time in which the French influence is well-established and any changes in the inflexional system of the language have already taken place. Extracts between 2,000 and 3,000 words of each have been selected thus totalling some 45,000 words (a sufficient amount of material for a first approximation to the topic). The corpus has been thus organised as shown in Table 1.

Table 1. Structure of the corpus.

\begin{tabular}{llr} 
Type of text & Title & Words \\
\hline Law & Statutes (II). The Statutes of the Realm (part of <sample 1>) & 2378 \\
$\begin{array}{l}\text { Documents } \\
\text { Handbooks, }\end{array}$ & Indenture, petitions (M4) (<sample 3>) & 2232 \\
medicine & The Liber de Diversis Medicinis (<sample 2>) & 2799 \\
Handbooks, others & Reynes, The Commonplace Book (<sample 1><sample 4>) & 2058 \\
Handbooks, & Metham's Days of the Moon & 2902 \\
astronomy & & 3080 \\
Science, medicine & The Cyrurgie of Guy de Chauliac (<sample 2>) \\
Sermons & ME Sermons from Ms Royal 18B.XXIII (incomplete sample) & 2710 \\
Rules & Aelred of Rievaulx's De Institutione Inclusarum & 1972 \\
Religious treatises & The Book of Margery Kempe (chapter 2 in <sample 2>) & 2291 \\
Prefaces & Caxton, Prohemye and epilogue of Polichronicon & 2175 \\
History & Gregory's Chronicle (<sample 1>) & 2759 \\
Biography & Life of Saint Edmund (not complete sample) & 3211 \\
Fiction & Caxton's The History of Reynard the Fox (part of <sample 1>) & 2119 \\
Romances & Malory's Morte Darthur (<sample 1>) & 3892 \\
Drama & Ludus Coventriae (<sample 2>) & 2270 \\
Letters, private & Two letters by Clement Paston (in <sample 2>) & 1856 \\
Letters, non-private & William Paston (part of the "Memorandum to Arbitrators") & 2496 \\
Bible & Rolle's The Psalter of Psalms of David (<sample 6>) & 2251 \\
\hline & &
\end{tabular}

Since we are dealing with attributive adjectives inside Noun Phrases, "absolute constructions" or free adjuncts of the type shown in (25) have been ignored.

(25) Woebegone and haggard, he went over every detail of it with his friends a hundred times (from Kortmann 1991: 7)

On the same grounds I have also disregarded those participles that function not as modifiers but as prepositions whose adjectival character has been lost (such as during) and participles clearly belonging to verbal periphrases (such as continuous tenses, passive voice, etc.) or to reduced relative clauses. 
I have also excluded mani, swylk, sum, and other forms whose lexical content does not denote a specific characteristic and that do normally precede the head of the Noun Phrase.

It has been difficult to deal with -ing forms in attributive function since not all of them were identical in function. Thus, there seems to be a difference between the two instances in (26).

(26) Preaching time (ChrLond) $=$ time to preach, time for preaching.

Sleeping baby $=$ baby that is sleeping.

I have considered that "preaching" in "preaching time" is not an adjective because when transforming it it becomes a complement clause, whereas "sleeping" in "sleeping baby" becomes a relative - or adjective - clause. This treatment has been applied to similar examples in order to disambiguate them.

Table 2 shows the distribution of adjectives in the selected corpus. From left to right, column 1 includes the total number of words in the sample; column 2 states how many of them are adjectives. Of all those adjectives, only the ones in attributive function have been counted (column 3). The relative position of such attributive adjectives in each sample text has been represented in columns 4 and 5 . For each column both the absolute numbers and percentages are given.

It is obvious that not all types of texts show the same amount of adjectives and this may be due, on the one hand, to the style of the author and, on the other, to the type of text itself. In this sense it is not surprising that "private letters" are the ones showing fewer adjectives (less than $2 \%$ ) since they are mainly informative and not descriptive pieces. This same argument seems to be valid for the text type containing the highest number of adjectives (227), namely "handbooks", because such handbooks were highly descriptive in the Middle Ages. However, it is percentages that we should take into account and, in this sense, "non-private letters" are in the lead with more than $8 \%$ of qualifying adjectives.

Table 2. Distribution of adjectives in the corpus.

\begin{tabular}{|c|c|c|c|c|c|c|c|c|c|}
\hline \multirow[t]{2}{*}{ Type of text } & \multirow[t]{2}{*}{$\begin{array}{c}\text { Total } \\
\text { words }\end{array}$} & \multicolumn{2}{|c|}{ Adjectives } & \multicolumn{2}{|c|}{ Attr. adjectives } & \multirow{2}{*}{$\begin{array}{c}\text { Pre- } \\
\text { adjs. } \\
\text { n. }\end{array}$} & \multicolumn{2}{|c|}{$\begin{array}{l}\text { Post- } \\
\text { adjs. }\end{array}$} & \multirow{2}{*}{$\begin{array}{c}\text { Other } \\
\text { n. } \\
\end{array}$} \\
\hline & & n. & $\%$ & n. & $\%$ & & n. & $\%$ & \\
\hline Law & 2378 & 166 & 6.9 & 153 & 92.2 & 137 & 14 & 9.1 & 0 \\
\hline Documents & 2232 & 60 & 2.6 & 52 & 86.6 & 44 & 8 & 15.4 & 0 \\
\hline Handbooks, medicine & 2799 & 111 & 3.9 & 73 & 65.7 & 66 & 5 & 6.9 & 2 \\
\hline Handbooks, others & 2058 & 92 & 4.5 & 53 & 57.6 & 45 & 7 & 13.2 & 1 \\
\hline Handbooks, astronomy & 2902 & 227 & 7.8 & 50 & 22 & 47 & 3 & 6 & 0 \\
\hline Science, medicine & 2710 & 114 & 4.2 & 52 & 45.6 & 52 & 0 & 0 & 0 \\
\hline Sermons & 2710 & 101 & 3.7 & 58 & 57.4 & 52 & 4 & 6.9 & 2 \\
\hline Rules & 1972 & 124 & 6.2 & 88 & 71 & 84 & 4 & 4.5 & 0 \\
\hline Religious treatises & 2291 & 74 & 3.3 & 51 & 68.9 & 50 & 1 & 1.9 & 0 \\
\hline Prefaces & 2175 & 167 & 7.6 & 140 & 83.8 & 133 & 7 & 5 & 0 \\
\hline History & 2759 & 76 & 2.7 & 66 & 86.8 & 61 & 5 & 7.6 & 0 \\
\hline Biography & 3211 & 157 & 4.9 & 112 & 71.3 & 110 & 2 & 1.8 & 0 \\
\hline
\end{tabular}




\begin{tabular}{lrrrrrrrrr} 
Fiction & 2119 & 78 & 3.7 & 53 & 67.9 & 48 & 5 & 9.4 & 0 \\
Romances & 3892 & 146 & 3.7 & 90 & 61.6 & 84 & 4 & 4.4 & 2 \\
Drama & 2270 & 113 & 4.9 & 68 & 60.2 & 59 & 9 & 13.2 & 0 \\
Letters, private & 1856 & 36 & 1.9 & 21 & 58.3 & 19 & 1 & 4.7 & 1 \\
Letters, non-private & 2496 & 221 & 8.8 & 211 & 95.4 & 197 & 13 & 6.1 & 1 \\
Bible & 2251 & 110 & 4.9 & 62 & 56.3 & 61 & 1 & 1.6 & 0 \\
\hline & 45451 & 2173 & 4.8 & 1453 & 66.8 & 1349 & 93 & 6.4 & 9
\end{tabular}

Since it is postponed attributive adjectives I am considering here it may be convenient to say that Mustanoja's (1960: 277) claim that legal formulae are the ones in which the so-called French Type (postponed attributive adjectives) is more often found seems to be proved as far as my data is concerned. Evidence from my corpus shows that "law" texts $(9.1 \%)$ and "documents" $(15.4 \%)$ - which could be included into the same group since many of such documents are of a legal sort - contain the biggest number of postponed adjectives. Examples of such French-type found in my samples are listed in (27). As can be seen, it is a fact that certain formulae containing words of Latin/French origin are repeated (such as spiritual and temporal). The rest of the postponed examples in (27) are past participles that were not accompanied by any complement, so that in this particular case the rhematic-weight factor claimed by certain authors for present day English should be left aside here and an explanation based on a more free word-order should be considered instead for late Middle English.

(27) Ev y Cite Bourgh and Towne walled (Stat2)

The rules aforseid (Stat2)

In tymes passed (Stat2)

Thassent of the lordes sp uall and temp ell (Stat2)

His Lordis Sp uall and temp ell (Stat2)

Assent of the lordes sp uall and temp all (Stat2)

Of the assent of the Lordes sp uall and temp all (Stat2)

My example (28) illustrates instances from the "document" text-type where postposition occurs again with participles or with words of French origin.

(28) +te xije. Day of Ianuer tte yere aboue said (Indent)

tte trouth in the mater a boue said (Indent)

no +ting varyeng in substance (Indent)

"Drama" comes next and, though further investigation should be needed to achieve definitive conclusions, I could say that it may be end-rhyme in my samples that forces post-position in many cases though most of my instances have, once more, an originally French element such as the suffix -able. Examples are given in (29).

(29) than haue I cawse bothe juste and Able (Ludus)

ffor my synnys Abhomynable (Ludus)

The only text-type in which no instances of postponed attributive adjectives have been found is "medicine" in a translation from a Latin text by Guy de Chauliac. It is 
well known that Latin has the order Adjective + Noun and this pattern seems to have been translated and easily assimilated into English as something absolutely natural. It seems then that the translator is here maintaining the Latin word-order pattern and syntactic structure of his original or source text.

No $-s$ plural suffix has been found in any of the adjectives in my corpus, not even in post-posed ones. This may mean that the French Type is not considered foreign any more by speakers of Middle English who have adopted it as their own and have consequently eliminated all non-English morphological features though the word-order has been preserved.

One last aspect deserves being commented here. I have included in my table a column under the label "others" in which I have wanted to gather all those adjectives that are not postponed regarding their governing head strictly speaking, but that show some peculiarity in their distribution. As a general rule - and as can be inferred from the examples in (30) - the fact that no pro-forms are required until the early Modern English period can be considered as one of the causes for the existence of such instances. Besides, in most cases it seems to be related to their inclusion in co-ordinate structures since it is patterns containing or, and, as well as, that seem to favour that the last of the two adjectives appears in final position.

(30) for is good lyvynge and vertuous (Royal)

the vij verkes of bodely mercye and of goostely bothe (Royal)

t te feste of Michelmesse + tan next folwyng (Wpaston1)

a good knyght and a trew (Malory)

I know hym nat lyvynge hys macche (Malory)

ij galouns of white wynne or rede (Thorn)

it is gude till alde wondis and to newe (Thorn)

tte goode humores schuldyn goon owte as well as tte wyk (Reynes)

this is as well learned a man

\section{Conclusion}

By way of conclusion I could say that though more research needs being carried out, this first approximation to the relative order of attributive adjectives in the Noun Phrase in the history of English shows that it seems to depend more on syntactic factors and on the etymological origin of the terms themselves than on morphological or any other type of constraints. In view of this, it seems reasonable to maintain the label "French type" for fossilised forms with post-posed attributive adjectives as the ones I have been dealing with in this paper.

Thus, claims such as Jespersen's or Mustanoja's for the existence of a French Type are backed by Markus's (1997: 487) when saying that there are certain "marginal" rules in English grammar governing word-order such as etymological background. The evidence from my corpus shows that this is true, but morphology must not be disregarded as a determining or restricting factor since I have seen that most postponed adjectives in my corpus are participles. That is to say, the existence of certain morphological properties may also imply having a particular place in the NP. 
The presence of the so-called French Type in the English language seems to have been bigger in the past than it is today and the etymological factors the label suggest are not to be considered the only cause. Once more, morphological, semantic and syntactic factors must be considered to be operating simultaneously. I have tried to demonstrate that besides these all such factors have been and still are at stake/issue here, though not all of them are equally relevant at all times.

ISABEL MOSKOWICH SPIEGEL-FANDIÑO Department of English Philology University of La Coruña 15071 LA CORUÑA isabel@udc.es

\section{REFERENCES}

Aarts, Bas

1997 English syntax and argumentation. London: Macmillan.

Aarts, Flor - Jan Aarts

1982 English syntactic structures, functions and categories in sentence analysis. Oxford: Pergamon Press.

Anderson, John

1993 "Parameters of syntactic change: A notional view", in: Charles Jones (ed.), 1-42. Bhat, Darbhe Narayana Shankara

1994 The adjectival category. Criteria for differentiation and identification. Berlin: Mouton de Gruyter.

Bichakjan, Bernard $\mathrm{H}$.

1987 "The evolution of word order: A paedomorphic explanation", in: A. Giacalone Ramat et al. (eds.), 87-108.

Blake, Norman F. (ed.)

1992 The Cambridge history of the English language. Vol II: 1066-1476. Cambridge: Cambridge University Press.

Canale, Michael

1976 “Implicational hierarchies of word order relationships", in: W.M. Christie (ed.), 39-70.

Christie, William M. (ed.)

1976 Current progress in historical linguistics. Amsterdam: North-Holland Publishing Company.

Fisiak, Jacek

1968 A short grammar of Middle English. Part One: Graphemics, phonemics and morphemics. London: Oxforf University Press.

Giacalone Ramat, Anna et al. (eds.)

1987 Papers from the 7th International Conference on Historical Linguistics. Amsterdam: John Benjamins. 
Greenberg, Joseph H.

1963 "Some universals of grammar with particular reference to the order of meaningful elements", in: Joseph H. Greenberg (ed.), 58-90.

Greenberg, Joseph H. (ed.)

1963 Universals of language. Cambridge, MA: The MIT Press.

Huddleston, Rodney

1984 Introduction to the grammar of English. Cambridge University Press.

Jespersen, Otto

1949 A Modern English grammar on historical principles. London: Allen and Unwin.

Jones, Charles (ed.)

1993 Historical linguistics: Problems and perspectives. London: Longman.

Kisbye, Torben

1971 A historical outline of English syntax. Aarhus: Nordisk Sprogog Kulturforlag.

Kortmann, Bernd

1991 Free adjuncts and absolutes in English. Problems of control and interpretation. London: Routledge.

Lass, Roger

1987 The shape of English. Structure and history. London: Dent.

1992 "Phonology and morphology", in: Norman F. Blake (ed.), 23-155.

Lyons, John

1981 Language and linguistics. An introduction. Cambridge: Cambridge University Press.

Markus, Manfred

1997 "The men present" vs "the present case": Word-order rules concerning the position of the English adjective", Anglia 115: 487-506.

Michael, Ian

1970 English grammatical categories and the tradition to 1800. Cambridge: Cambridge University Press.

Mitchell, Bruce

1985 Old English syntax. Oxford: Clarendon Press.

Mustanoja, Tauno F.

1960 A Middle English syntax. Part 1: Parts of speech. Helsinki: Société Néophilologique.

Quirk, Randolph et al.

1972 A grammar of contemporary English. London: Longman.

Rusiecki, Jan

1985 Adjectives and comparison in English. A semantic study. London: Longman. 
